\title{
Employee Engagement; Tool of Talent Retention: Study of a Pharmaceutical Company ${ }^{\#}$
}

\author{
Poonam Jindal ${ }^{1 *}$, Mohsin Shaikh ${ }^{2}$ and G. Shashank ${ }^{3}$ \\ 'Research Scholar, Pune University and Assistant Professor HR/OB,Vignana Jyothi Institute of Management, Hyderabad, India \\ ${ }^{2}$ Professor \& Head, Department of Management Studies, SKN College of Engineering, Pune, India \\ ${ }^{3} \mathrm{PGDM}, \mathrm{VJIM}$, Hyderabad, India
}

\begin{abstract}
Research article is a study of employee engagement at a pharma company located in Hyderabad. The main focus of this study is to understand the factors which influence employee engagement and to find the level of employees engaged at this pharma company located in Hyderabad. Research indicates that companies whose level of engaged employees are higher have less attrition rate than other companies and also is marked higher in productivity and customer satisfaction, so this proves that result of employee engagement are impacting the result in bottom line. For the purpose of the study a questionnaire was prepared based on understanding various aspects of company, relationship with the manager and the job. The questionnaire was checked for validation and reliability and responses were collected from employees who are working at a division on this pharma company in Hyderabad. The data analysis of the responses has resulted in some findings on gender \& flexible policies, experienced employees \& interaction, experienced employees \& appreciation and level of engaged employees. If it is not taken care on time such issues can lead to high attrition rate in company. Happy employees keep customers happy. Pharmaceutical sector being a sector of critical talent, the retention of talent is a huge responsibility for HR. To improve the engagement among the employees, based on findings some of the engagement activities like opportunities to share feedback on manager, acknowledge employee contribution on real time basis, paternity leave policy were suggested in the study to retain employees.
\end{abstract}

Keywords: Employee engagement, Retention, Flexible work policy, Talent management, Engagement levels

\section{Introduction}

Modern management knows that modern business demands higher output and more competence, than in earlier times. Companies are trying to increase their performance in order to place their company ahead of the competitors. HR experts in India remain to struggle with talent management problems, mainly retention. The huntto retain employees has taken HR experts through concepts such as employee satisfaction, employee delights etc. An idea of "Employee
Engagement" is the level of emotionally bonding an employee has to his organization and ardent about his work.

Engagement is about making your employees feel to do their best. Anengaged employee puts his or her hundred percent to in his or her company and work. The quality of output and competitive advantage of a company depends upon the quality of people who work there. It has been proved that there is a link between employee engagement, customer loyalty and

\footnotetext{
*Email: poonam.j@vjim.edu.in

"Revised and modified version of the paper, presented in the $5^{\text {th }}$ International Conference on "Managing $\mathrm{HR}$ at the workplace, SDMIMD, December 2016.
} 
profitability. Organizations actively pursue higher levels of employee engagement to increase productivity, imbue positive energy within the corporate culture, and enhance organizational reputation within the industry or the broader business community. (Simon L. Albrech, 2011) "Handbook of Employee Engagement: Perspectives, Issues, Research and Practice".

Through the literature from diverse sections, research offered a series of proposals about behavioral engagement, psychological state engagement; and trait engagement. In addition, it proposed intentions regarding the effects of job attributes and leadership as main effects on state and behavioral engagement and as moderators of the relationships among the 3 facets of engagement. (William $\mathrm{H}$. Macey, Valtera Corporation; Benjamin Schneider, 2008).

Studies have shown that fully engaged employees perform better than those who are disengaged. Specifically, these employees exhibit intense organizational performance, increased financial success, elevated productivity, and are retained more than their disengaged employees.

HR plays a very crucial role in keeping the employees engaged. Both employee engagement and retention are closely related. And this relationship has an impact on the top revenues and the bottom-line.

The Academic researchers and HR consulting firms are offering their own understandings of the meaning of the construct. Some of the points presented by the researchers are balancing and they agree that engagement procedures the prospect for employees to attach closely with their managers, co-workers and organization in general and the engaging environment is the environment where employees have positive attitude toward their job and are willing to do high-quality job.

\section{Literature Review}

Employee engagement is generally the level of commitment and involvement an employee has towards their organization and its core value and beliefs. An engaged employee is acknowledged to be conscious of business situations, and work subtleties with colleagues and groups to expand performance with the job for advantage and excellence of the organization. It is a positive attitude held by the employees towards the organization and its values. It leads to optimistic employee behavior that leads to organizational accomplishment.

Higher levels of engagement in domestic and global and domestic firms encourage retention of talent, fetches customer loyalty and expand organizational performance and stakeholder value. (Nancy R. Lockwood, 2007)

As organizations have anticipated more from their workforce and have provided little in return other than simply a job or employability, it is may be not surprising that employee pessimism and distrust have increased. (Susan Cartwrite and Nicola Holmes, 2006)

One study shows that there is a significant difference between job engagement and organization; with showing that the co-employee support is a major individual factor that influences both measures of engagement and the work outcomes. (Alogbo C. Andrew \& Saudah Sofian, 2012).

Employee engagement is the emotional connection an employee has towards the organization and which impacts his performance and efforts in work. It involves:

- The nature of job or work one does.

- The communication system and trust employee has in management.

- The capabilities of employee to contribute as performance.

- The opportunities one gets for growth and development.

- The employer brand brings the pride in an employee to be associated with a company.

Kanrad (2006) states that employee engagement has three related components: a cognitive; a behavioral, and an emotional aspect. The cognitive part of employee engagement covers employee's beliefs about the working conditions, organization, and its leaders. The emotional aspect covers what attitude the employee has 
about the company, whether employees have positive or negative attitude towards organization and its leaders. The behavioral aspect is about the value addition by the employees for the organization and comprises the discretionary efforts an engaged employee brings to work in the form of extra time and energy.

Employee engagement means the functional and emotional connection from the employee towards their organization. Employee engagement doesn't mean that making employee satisfied or making employee happy, because a satisfied employee may leave the organization for the better salary and good opportunities in other companies and a happy employee might not be productive and hardworking at his work place, he might be happy due to various other reasons (company's facilities etc...). The employee is called as engaged when he is self-driven, passionate, and innovative at his workplace (Kevine Kruse, 2012).

A fully engaged employee doesn't just work for salary, promotion or any self-objectives but he works for the organizational objectives. The more level of engaged employees in the organization leads to higher profits (Towers Perrin Research Company, 2012).

Employee engagement is the state of mind which is measured by performance and productivity of the employees and it is also supported by prioritizing some of the key elements such as planning, recognition, communication and contribution (Kim Monaghan, 2016).

The expenses on employee engagement programs are huge for the company. Although there is a strong correlation between employee engagement and business performance but there is no proof that the former causes the latter. Instead of investing in employee engagement programs organization can invest where employee gets more clarity, develop effectiveness and increase commitment (Ann Latham, 2015).

The word 'engagement' is limiting because it assumes that purpose is to engage people rather than building the organization with meaningfulness, fun, valuable and exciting (Josh Bersin, 2014).
The companies whose level of engaged employees is higher has less attrition rate than other companies and also is marked higher in productivity and customer satisfaction, so this proves that result of employee engagement also shows result in bottom line (Gallup's survey, 2015).

The benefits of the employee engagements are reflected on productivity, performance and reduce absenteeism, reduce disputes, reduce staff turnover and also improves the skill and knowledge of the employees (charted institute for professional development, 2009).

Passionate performance is defined as strong, sustained intellectual and emotional attachment to one's work. Engaged minds build employee performance and engaged hearts ignite employee's passion. Passionate performance is all about performance and passion.

\subsection{Characteristics of Passionate Performers}

- Employees are enthusiastic and deliver good results

- Team will have more fun in creating better outcomes

- Employees are fully present at work, in the moment and in the flow

- They look like people performing at higher levels

- Work for them feel like play

- They are passionate about the work. They look forward to come to work and love the work

- They feel they are important part in big picture.

When basic needs are fulfilled they can strike the passionate performance and engage their hearts and minds. Basic needs are two types 1 . Intellectual needs 2. Emotional needs

Engaged minds build employee performance and engaged hearts ignite employee's passion.

Discretionary efforts: are people willing to do extra time and extra effort to achieve team goals.

\subsection{Employees Give Discretionary Efforts When}

- Choose to work late to complete the project 
- Ask how can they serve better to another team

- Inquire about how their actions affect another functions

- Makes a connections with their decision and company's financial results

- Treat company's resources as their own

- Initiate improvements in work methods

- Look beyond their own roles for improvement opportunities

- Invests in self-development in their personal time.

\subsection{Disengaged Employees}

Gallup survey found that disengaged workers are tend to be less productive, less loyal, less satisfied, more stressed and insecure about their work.

\subsubsection{Symptoms of Disengagement}

- Increased turnover

- Missed deadlines

- Low morale

- High burnouts

- Complacency

- Lack of accountability and responsibility

- Increased absenteeism

Disengagement is simply because of unfulfilled needs

\subsubsection{Disengaged Employees}

They keep looking at the clock. They left their heart and mind at home.

\subsubsection{Actively Disengaged Employees}

They feel unhappy and demonstrate their feelings to their managers and coworkers. (Lee J. Colan, 2009)

\section{Objective of the Study}

- To identify the factors that contribute to the employee engagement.

- To study the associations between key demographics and key aspects of employee engagement.

\section{Research Methodology}

To achieve the objectives of the study, a questionnaire was prepared and each question is built on a factor of employee engagement. The study was undertaken with a well-structured questionnaire duly filled by respondents with varying demographic and departments. The data for the study was collected using both primary and secondary sources. The sample size of the study was 122 and simple random sampling technique was used.

The study helps understand the various factors which influence the employee's engagement and also shows the importance levels given to each of the variables under various factors from the perceptions of the employees.

The data required for the study was collected using the questionnaire which consisted general demographic information about the respondents such as age, gender, qualification, and department. The questionnaire also consists study related questions which were designed with an aim to understand the level of engagement taking into consideration factors like company, job, and relationship with manager of the employees. The secondary data for the study was taken from the HR department of the company, books, official websites, newspapers, e-journals and published sources.

The data obtained was analyzed using IBM SPSS Version 24.0 software. Following methods were used for analyzing the data obtained through questionnaire.

- Graphical analysis

- Chi-square test for association

- Exploratory Factor Analysis

The following are the factors identified from literature review to prepare the questionnaire:

1. Company

- Being loyal

- Pride in working for company

- Organizational citizenship

2. Relationship with manager

- Accelerated coaching and career support

- Recognition

- Accountability

- Work group/Team

3. Job

- Clarity of roles and responsibilities

- Physical setting of work

- Safety 
Table 1. Literature extracts

\begin{tabular}{|c|c|c|}
\hline Sl. No. & Definition & Given by \\
\hline 1 & 'Harnessing of the organizational members' to their work roles & Kahn (1990) \\
\hline 2 & The amount of discretionary effort exhibited by the employees in their job roles & Frank et. al. (2004) \\
\hline 3 & Emotional and intellectual commitment to the organization & $\begin{array}{l}\text { Baumruk (2004), Richman } \\
\text { (2006), Shaw (2005) }\end{array}$ \\
\hline 4 & $\begin{array}{l}\text { It is a required condition, has an organizational purpose and meanspassion, enthusiasm, participation, obligation, } \\
\text { focused effort, and energy, so it has both attitudinal and behavioral components. }\end{array}$ & Erickson (2005) \\
\hline 5 & $\begin{array}{l}\text { The state by which individuals are emotionally and intellectually committed to the organization or group, as measured by } \\
\text { the three primary behaviors: } \\
\text { - } \quad \text { Speaking positively about the organization to co-workers and referring it to potential employees and customers. } \\
\text { - } \quad \text { Having an intense desire to be a member of the organization, despite having opportunities to work elsewhere. } \\
\text { - } \quad \text { Exerting extra effort and exhibiting behaviors that contributes to business success. }\end{array}$ & Lockwood (2005) \\
\hline 6 & $\begin{array}{l}\text { It is a result of employees' organizational involvements that are considered by behaviors that can be grouped in to three } \\
\text { categories such as say, stay and strive }\end{array}$ & Hewitt (2005) \\
\hline 7 & $\begin{array}{l}\text { Progressive amalgamation of motivation,satisfaction, commitment, and advocacy resulting from employees' progression } \\
\text { up the engagement pyramid. }\end{array}$ & Brown (2006) \\
\hline 8 & $\begin{array}{l}\text { Employee engagement is a state of employee who feels committed, passionate, involved, and empowered and reveals } \\
\text { those feelings in work behavior }\end{array}$ & Mone and London (2010) \\
\hline
\end{tabular}

Table 1 above gives the extracts from the literature review and was used to build the questionnaire.

\section{Data Analysis and Interpretation}

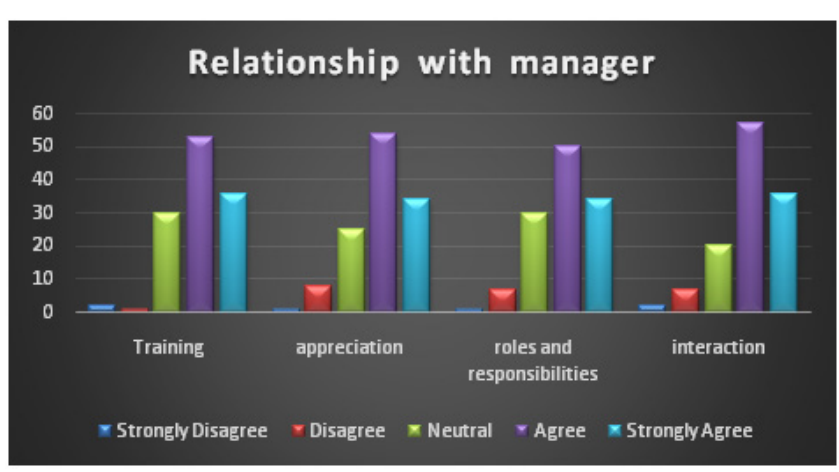

Figure 1. Sample division based on Gender.

Table 1. Description of the sample division based on gender

\begin{tabular}{|l|l|}
\hline Gender & Total \\
\hline Male & 92 \\
\hline Female & 30 \\
\hline Total & 122 \\
\hline
\end{tabular}

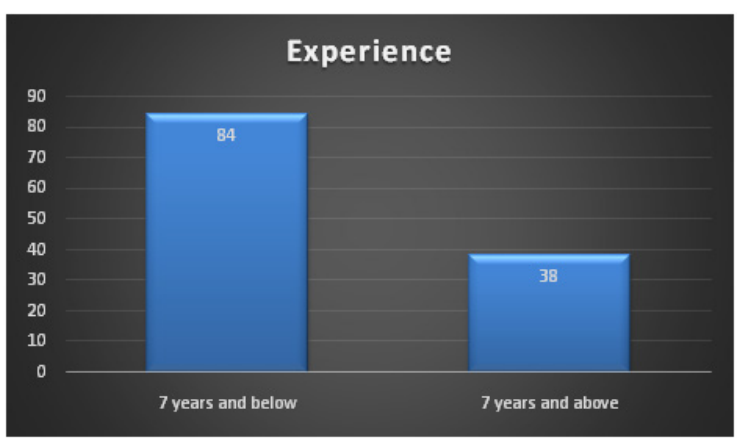

Figure 2. Sample division based on experience.
Table 2. Sample division based on experience

\begin{tabular}{|l|l|}
\hline \multicolumn{2}{|l|}{ Experience at Company } \\
\hline 7 years and below & 84 \\
\hline 7 years and above & 38 \\
\hline Total & 122 \\
\hline
\end{tabular}

\subsection{Factor Analysis to Find the Factors Associated with the Employee Engagement}

Factor analysis helps to find out the three main factors that have to be considered while studying the employee engagement in Pharmaceutical companies.

Graph 3 indicates the number of factors extracted by the analysis. One can note that first three components have their Eigen values more than one and form the set of factors that can de used to explain the employee engagement.

Table 3 indicates that $65.5 \%$ of the variance in employee engagement is explained by the three factors extracted. This indicates that the factors will help one to explain the employee engagement to an extent of $65 \%$. That is, one can be assured of $65 \%$ of understanding whether employees are engaged, using the three factors. 


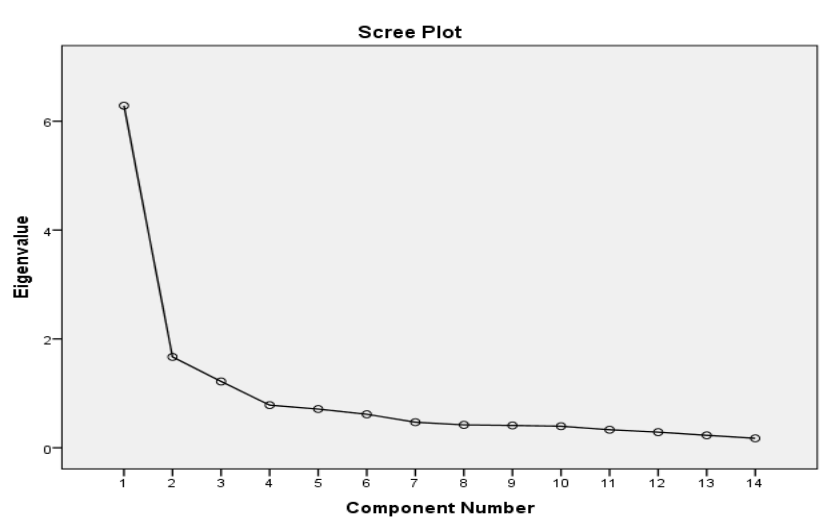

Figure 3. Scree plot showing the factors.

Table 3. Total variance explained

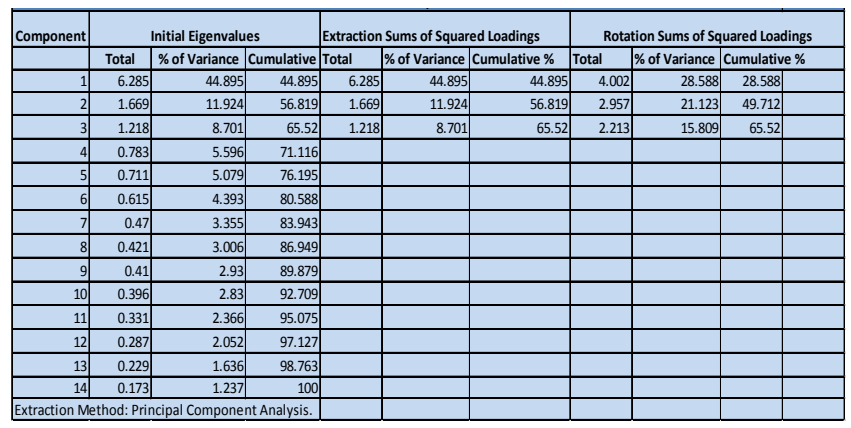

Table 4 above is used to identify the variables under each of the factor.

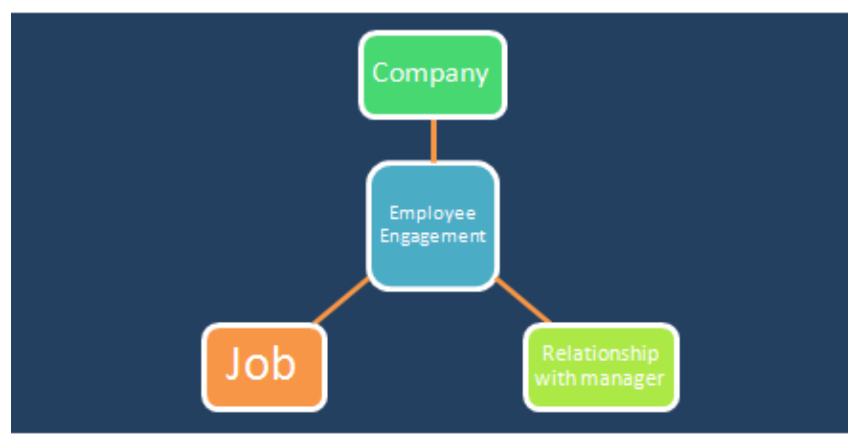

Figure 4. Factors obtained.

Figure 4 gives the three factors identified along with the employee engagement. The variables under each of the factors are listed separately in the following tables. One can note that the split into factors have given an opportunity to study the opinion of the employees separately.
Table 4. Rotated component matrix

\begin{tabular}{|l|l|l|l|}
\hline \multicolumn{4}{|l|}{ Component } \\
\cline { 2 - 4 } & 1 & 2 & 3 \\
\hline Company's mission is very well connected to me. & 0.184 & 0.265 & 0.779 \\
\hline My teammates support me in my work. & 0.566 & 0.047 & 0.561 \\
\hline $\begin{array}{l}\text { I get recognized among the public, when I say I'm } \\
\text { from } x \text { Company. }\end{array}$ & 0.176 & 0.128 & 0.807 \\
\hline $\begin{array}{l}\text { I would recommend my company as a great place } \\
\text { to work. }\end{array}$ & 0.449 & 0.311 & 0.527 \\
\hline $\begin{array}{l}\text { My L+1 provides me training whenever it's } \\
\text { required for me. }\end{array}$ & 0.766 & 0.146 & 0.258 \\
\hline My L+1 appreciates me for my work. & 0.832 & 0.062 & 0.171 \\
\hline $\begin{array}{l}\text { My L+1 communicates my job roles and } \\
\text { responsibilities with clarity. }\end{array}$ & 0.826 & 0.196 & 0.153 \\
\hline $\begin{array}{l}\text { HR policies provide me with flexibility to meet my } \\
\text { work and personal responsibilities }\end{array}$ & 0.278 & 0.731 & 0.072 \\
\hline $\begin{array}{l}\text { The career opportunities provided by the } \\
\text { organisation are helpful for my future growth. }\end{array}$ & 0.504 & 0.582 & 0.067 \\
\hline The activities of Safety team make me feel safe. & -0.094 & 0.662 & 0.32 \\
\hline My L+1's interaction with me is good. & 0.816 & 0.202 & 0.128 \\
\hline My HR's interaction with me is good. & 0.273 & 0.829 & 0.038 \\
\hline $\begin{array}{l}\text { I am recognized for my achivements in the events } \\
\text { conducted by Dr.Reddy's. }\end{array}$ & 0.608 & 0.489 & 0.243 \\
\hline $\begin{array}{l}\text { I am aware of company's organizational and HR } \\
\text { policies. }\end{array}$ & 0.074 & 0.655 & 0.232 \\
\hline
\end{tabular}

Extraction Method: Principal Component Analysis.

Rotation Method: Varimax with Kaiser Normalization. ${ }^{\text {a }}$

a. Rotation converged in 6 iterations.

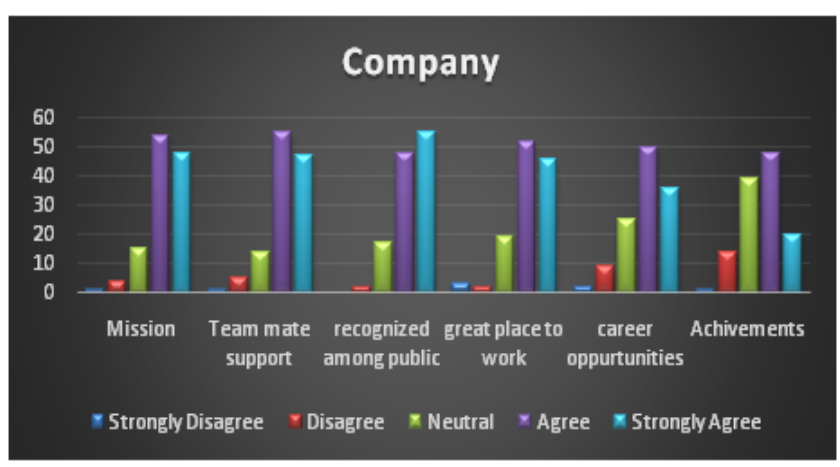

Figure 5. Variables under the factor company.

From the table 5 and figure 5 , one can note that, among other variables under the factor "Company", "recognized among public" is given more importance followed by mission and team mate support. From this we conclude that, an employee gets more engaged and works hard for his company if it is well known among the public (which indicates a symbol of status for the employee), Mission of the company (that motivates 
Table 5. Factor-1: Company

\begin{tabular}{|l|l|l|l|l|l|l|}
\hline Factors & Strongly Disagree & Disagree & Neutral & Agree & Strongly Agree & Total employees \\
\hline Mission & 1 & 4 & 15 & 54 & 48 & 122 \\
\hline Team mate support & 1 & 5 & 14 & 55 & 47 & 122 \\
\hline Recognized among public & 0 & 2 & 17 & 48 & 55 & 122 \\
\hline Great place to work & 3 & 2 & 19 & 52 & 46 & 122 \\
\hline Career opportunities & 2 & 9 & 25 & 50 & 36 & 122 \\
\hline Achievements & 1 & 14 & 39 & 48 & 20 & 122 \\
\hline
\end{tabular}

Table 6. Factor-2: The Job

\begin{tabular}{|l|l|l|l|l|l|l|}
\hline Factors & Strongly Disagree & Disagree & Neutral & Agree & Strongly Agree & Total employees \\
\hline HR Policies & 1 & 2 & 14 & 66 & 39 & 122 \\
\hline Safety & 4 & 19 & 30 & 48 & 21 & 122 \\
\hline HR Interaction & 2 & 2 & 22 & 63 & 33 & 122 \\
\hline Policies & 2 & 12 & 29 & 47 & 32 & 122 \\
\hline
\end{tabular}

Table 7. Factor-3: Relationship with Manager

\begin{tabular}{|l|l|l|l|l|l|l|}
\hline Factors & Strongly Disagree & Disagree & Neutral & Agree & Strongly Agree & Total \\
\hline Training & 2 & 1 & 30 & 53 & 36 & 122 \\
\hline Appreciation & 1 & 8 & 25 & 54 & 34 & 122 \\
\hline Roles and responsibilities & 1 & 7 & 30 & 50 & 34 & 122 \\
\hline Interaction & 2 & 7 & 20 & 57 & 36 & 122 \\
\hline
\end{tabular}

him to achieve the goals), and team mate support (that makes him comfortable in the company). Of course, other variables also have been importance, but relatively the above mentioned variables have to be given the top priority. In all the three cases, we have considered the sum of frequencies given to agree and strongly agree, to arrive at the important variables.

From figure 6, one can observe that HR policies and HR interaction (agree + strongly agree) makes an employee more engaged. A company with a good and transparent HR policy gives an employee the expectations the company has on him/her and at the same time the benefits he/she gets in the company. When there is a need for an employee, at times of crises or any other need,it is very important for the HR manager to interact and sort out the issues. This study finds that, these two are key factors in "The Job" factor for a better employee engagement.

It is interesting to note from the above graphs that, all the variables under the factors have been given equal importance.
From the above factor analysis, we conclude that, if one wishes to understand whether an employee is engaged or not, then obtaining the information on the three factors listed is sufficient. Also, the companies can focus and take care of the variables listed under each factors to ensure that the employee is satisfied with these variables, which ultimately makes an employee feel comfortable and feels engaged in the company.

We now study the association between key demographics and key aspects of employee engagement.

From tables 8 and 9, one can note that, p-value is less than .05 and null hypothesis is rejected. This indicates that, there is a significance dependency in gender of employees and flexibility the HR policies give them. $83.3 \%$ of the women agreed that HR policies provide them with flexibility to meet their work and personal responsibilities. This indicates that women in the selected pharma company are happy. $58.7 \%$ of the men agreed that HR policies provide them with flexibility to meet their work and personal responsibilities. From this analysis, we conclude that any company that want 
to have better employee engagement, has to consider the flexibility in HR policies. Also, the expectations are slightly different for male and female.

Table 8. Studying the association between gender and flexibility.

\begin{tabular}{|c|c|c|c|c|c|c|}
\hline Crosstab & & & & & & \multirow{3}{*}{ Total } \\
\hline \multicolumn{6}{|c|}{ Flexibility } & \\
\hline & & & Disagree & Neutral & Agree & \\
\hline \multirow[t]{4}{*}{ Gender } & Male & Count & 13 & 25 & 54 & 92 \\
\hline & & $\%$ within Gender & $14.10 \%$ & $27.20 \%$ & $58.70 \%$ & $100.00 \%$ \\
\hline & Female & \begin{tabular}{|l|} 
Count \\
\end{tabular} & 1 & 4 & 25 & 30 \\
\hline & & $\%$ within Gender & $3.30 \%$ & $13.30 \%$ & $83.30 \%$ & $100.00 \%$ \\
\hline \multirow[t]{2}{*}{ Total } & & Count & 14 & 29 & 79 & 122 \\
\hline & & $\%$ within Gender & $11.50 \%$ & $23.80 \%$ & $64.80 \%$ & $100.00 \%$ \\
\hline
\end{tabular}

Table 9. Chi-Square test results

\begin{tabular}{|l|r|r|r|}
\hline & Value & Df & Asymptotic Significance (2-sided) \\
\hline Pearson Chi-Square & $6.242 a$ & 2 & 0.044 \\
\hline Likelihood Ratio & 7.008 & 2 & 0.03 \\
\hline Linear-by-Linear Association & 5.889 & 1 & 0.015 \\
\hline N of Valid Cases & 122 & & \\
\hline
\end{tabular}

Table 11. Chi-Square test results

\begin{tabular}{|l|l|l|l|}
\hline & Value & df & $\begin{array}{l}\text { Asymptotic Significance } \\
\text { (2-sided) }\end{array}$ \\
\hline Pearson Chi-Square & $7.432 \mathrm{a}$ & 2 & 0.024 \\
\hline Likelihood Ratio & 7.329 & 2 & 0.026 \\
\hline Linear-by-Linear Association & 0.142 & 1 & 0.706 \\
\hline N of valid Cases & 122 & & \\
\hline
\end{tabular}

Tables 10 and 11 give the results of association between experience and $\mathrm{L}+1$ interaction.

Since $\mathrm{p}$ value is less than 0.05 , we reject null hypothesis and conclude that, there is a significance difference between experience of the employees and $\mathrm{L}+1$ interaction. $79.8 \%$ of the employees who have experience of 7 and below years in company agreed that they have good interaction with their manager and $68 \%$ of employees who has experience of more than 7 and above agreed that they have good interaction with their manager. From this we conclude that, interaction with manager is an important aspect with respect to the study of employee engagement.

From tables 12 and 13 we can see that, $\mathrm{p}$ value is less the .05 , the null hypothesis is rejected and we conclude that, there is a significance dependency in experience of the employees and L +1 's appreciation for employees work. $78.6 \%$ of the employees who has experience of 7 and below years in company agreed that they are appreciated by their managers and $57.9 \%$ of employees who has experience of more than 7 and above agreed that they are appreciated by their managers.

Table 10. Studying the association between Experience and interaction with Manager

\begin{tabular}{|c|c|c|c|c|c|c|}
\hline \multicolumn{7}{|c|}{ Crosstab } \\
\hline \multicolumn{6}{|c|}{ My $L+1$ 's interaction with me is good. } & \multirow[t]{2}{*}{ Total } \\
\hline & & & Disagree & Neutral & Agree & \\
\hline \multirow[t]{4}{*}{ Experience in company's } & 7 years and below & Count & 8 & 9 & 67 & 84 \\
\hline & & \% within Experience in company's & $9.50 \%$ & $10.70 \%$ & $79.80 \%$ & $100.00 \%$ \\
\hline & 7 years and above & Count & 1 & 11 & 26 & 38 \\
\hline & & \% within Experience in company's & $2.60 \%$ & $28.90 \%$ & $68.40 \%$ & $100.00 \%$ \\
\hline \multirow[t]{2}{*}{ Total } & & Count & 9 & 20 & 93 & 122 \\
\hline & & $\%$ within Experience in company's & $7.40 \%$ & $16.40 \%$ & $76.20 \%$ & $100.00 \%$ \\
\hline
\end{tabular}

Table 12. Studying the association between Experience and Manager's appreciation

\begin{tabular}{|l|l|l|l|l|l|l|}
\hline \multicolumn{9}{|c|}{ Crosstab } \\
\hline \\
\hline
\end{tabular}


Table 13. Chi-Square test results

\begin{tabular}{|l|l|l|l|}
\hline & Value & df & $\begin{array}{l}\text { Asymptotic Significance } \\
\text { (2-sided) }\end{array}$ \\
\hline Pearson Chi-Square & $9.085 \mathrm{a}$ & 2 & 0.011 \\
\hline Likelihood Ratio & 8.545 & 2 & 0.014 \\
\hline $\begin{array}{l}\text { Linear-by-Linear } \\
\text { Association }\end{array}$ & 2.141 & 1 & 0.143 \\
\hline N of valid Cases & 122 & & \\
\hline
\end{tabular}

\section{Conclusion}

The findings of the study show that men have more issues of interrupting non-work time that women, as the experience increases in the company employees have less interaction with their supervisors, and they get less appreciation for their achievements from their supervisors. It helps to build a competitive edge for an organization by positively engaging its employees. Key ingredients of effective employee engagement are having in place an appropriate leadership style and effective two-way communications with employees. This creates an open and honest environment where employees feel that their ideas are being listened to and that they can make a contribution to decision making. Engaged employees are more likely to be proud to work for their organization and therefore will believe in and live out the values of the organization. Employee engagement is the most important aspect for the company. It combines the factors related to company, relationship with the manager and the job. To sustain the growth rate of the company engaging the employees can be improved by commitment from employees as well as the senior management team. The result of employee engagement activities practiced at this company is positive because the level of the employee engagement is way high from the engagement levels in pharma organizations worldwide. There is the scope of further study in the same field by increasing the sample size in term of the employees from one company or number of companies in pharma. Employee engagement is a wide topic to research and an important tool to retain the best talent in organization.

\section{Bibliography}

Albrech, S. L. (2011). Handbook of employee engagement: Perspectives, issues, research and practice. Human Resource Management International Digest, 19(7).

Andrew, O. C., \& Sofian, S. (2012). Individual factors and work outcomes of employee engagement. ProcediaSocial and Behavioral Sciences, 40, 498-508.

Association, A. P. (2016). Work-life fit linked to employee engagement, motivation and job satisfaction. Retrieved August 3, 2016, Crossref

Bersin, J. (2014, April 10). It's time to rethink the "employee engagement" issue. Forbes. Crossref

Bhatnagar, J. (2007). Talent management strategy of employee engagement in Indian ITES employees: key to retention. Employee relations, 29(6), 640-663.

Cartwright, S., \& Holmes, N. (2006). The meaning of work: The challenge of regaining employee engagement and reducing cynicism. Human Resource Management Review, 16(2), 199-208.

Colan, L. (2008). Engaging the hearts and minds of all your employees: How to ignite passionate performance for better business results. McGraw Hill Professional.

Council, F. C. (2016, April 8). Employee engagement is not just A state of mind. Forbes. Crossref

Crawford, E. R., LePine, J. A., \& Rich, B. L. (2010). Linking job demands and resources to employee engagement and burnout: a theoretical extension and meta-analytic test. Journal of Applied Psychology, 95(5), 834.

Employee engagement and happiness starts with role clarity. (2014, January 28). Retrieved August 3, 2016, Crossref

Estep, M. (2014). Promoting pride in your business to improve service. Crossref

Frank, F. D., Finnegan, R. P., \& Taylor, C. R. (2004). The race for talent: Retaining and engaging workers in the 21st century. People and Strategy,27(3), 12.

Gallup, I. (2013, October 8). Worldwide, 13\% of employees are engaged at work. Crossref

Harter, J. K., Schmidt, F. L., \& Hayes, T. L. (2002). Businessunit-level relationship between employee satisfaction, employee engagement, and business outcomes: a metaanalysis. Journal of applied psychology, 87(2), 268.

Improving work group performance using better employee engagement. Retrieved August 3, 2016, Crossref 
Jindal, P., \& Shaikh, M. (2015). A Study of Behavioral Training as Talent Management Strategy in Organisations. Universal Journal of Management,3(1), 1-6.

Kahn, W. A. (1990). Psychological conditions of personal engagement and disengagement at work. Academy of management journal, 33(4), 692-724.

Kruse, K. (2012, June 22). What is employee engagement. Forbes. Crossref

Latham, A. (2015, November 1). 10 reasons your employee engagement program is hurting your company. Forbes. Crossref

Little, B., \& Little, P. (2006). Employee engagement: conceptual issues. Journal of organizational culture, communication and conflict, 10(1), 111.

Lockwood, N. R. (2005). Employee engagement. SHRM Research Briefly Stated. Retrieved on January, 27, 2008

Lockwood, N. R. (2007). Leveraging employee engagement for competitive advantage. Society for Human Resource Management Research Quarterly, 1, 1-12.

Luthans, F., \& Peterson, S. J. (2002). Employee engagement and manager self-efficacy. Journal of management development, 21(5), 376-387

Macey, W. H., \& Schneider, B. (2008). The meaning of employee engagement. Industrial and organizational Psychology, 1(1), 3-30.
Mone, E. M., \& London, M. (2014). Employee engagement through effective performance management: A practical guide for managers. Routledge.

Retrieved August 3, 2016, Crossref

Retrieved August 3, 2016, Crossref

Retrieved August 3, 2016, Crossref

Robinson, D., Perryman, S., \& Hayday, S. (2004). The drivers of employee engagement. Institute for Employment Studies.

Saks, A. M. (2006). Antecedents and consequences of employee engagement. Journal of managerial psychology, 21(7), 600-619.

Sundaray, B. K. (2011). Employee engagement: a driver of organizational effectiveness. European Journal of Business and Management, 3(8), 53-59.

Wagner, R. (2015, August 7). Stop using employee friendships to measure engagement. Retrieved from Leadership \& Managing people, Crossref

Watson, W. T. (2014, August ). The 2014 global workforce study. Retrieved August 3, 2016, Crossref 